\title{
Evaluation and Assessment in Early Social Science
}

\author{
Vlasta Hus ${ }^{1, *}$, Jasmina Matjašič̌ \\ ${ }^{1}$ Faculty of Education, University of Maribor, Slovenia \\ ${ }^{2}$ Elementary School, Slovenia
}

Copyright $\mathrm{O} 2017$ by authors, all rights reserved. Authors agree that this article remains permanently open access under the terms of the Creative Commons Attribution License 4.0 International License

\begin{abstract}
Authenticity is an important element in the newer models of teaching, evaluation and assessment. Due to the fact that it is quite unclear how authentic evaluation and assessment should be implemented into practice, teachers still cling too much to traditional forms of knowledge evaluation and assessment. First, some basic theoretical facts on evaluation and assessment with an emphasis on authentic evaluation and assessment are listed. Next, an outline of empirical research findings on the characteristics of evaluation and assessment in the subject Social Science in Year 4 is presented. Data were obtained by a web questionnaire on a representative sample of teachers who were teaching the subject Social Science in Year 4 at various primary schools in Slovenia. We discovered that teachers very commonly use summative knowledge evaluation and assessment form. Among the authentic and alternative forms research and simulation are predominant.
\end{abstract}

Keywords Primary School, Social Science, Evaluation, Assessment, Teacher, Year 4

\section{Introduction}

Evaluation and assessment are concepts which teachers use and are familiar with, but the distinction between them is quite complicated because both the scholarly literature and everyday communication do not offer unambiguous understanding. Some believe that it is necessary to clearly distinguish between the two terms, since they involve two completely different processes, while others think that assessment is the continuation of evaluation. The third party believes that they are actually almost entirely the same processes which differ only in the last stage where only in the assessment a feedback comes in the form of a mark [7].

Evaluation is the process of gathering information on learning and pupils' understanding of the discussed learning content. In order to monitor pupils' progress different methods are used (i.e. observation, discussions, checklists, anecdotal records etc.) [16].

Assessment is the process of finding and interpreting evidence to be used by learners and teachers in order to enable them to establish exactly where the learners are in their learning, where they have to focus and what best way to get there is [30].

Strmčnik [8] states that assessment is an independent level of learning process with its own specific didactic function, and does not coincide either with evaluation or practice. At the assessment stage there are marks, which are not an option at the evaluation stage.

After teacher's evaluating students' knowledge they can assess in different ways: verbal and written answers, oral presentations, artistic, technical, practical and other assignments, project work, etc. Based on the goals and standards of knowledge in the curriculum a teacher forms clear aspects and criteria for knowledge assessment, the methods used etc. in advance, and presents them to students [23].

When evaluating and assessing knowledge the atmosphere of an environment where these processes take place is also very important. Students need to feel safe and accepted in this environment, not-knowing should present a challenge and motivation for learning to students, and differences between the pupils should be taken into account and respected [21].

\subsection{Authentic Forms of Evaluation and Assessment}

Authentic assessment activities are designed to mimic the complexity of 'real world' situations that students may encounter in life, and require the application of a combination of skills related to knowledge, skills and attitude [13].

Wiggins (cited in [31]) states the basic characteristics of the authentic forms of evaluation and assessment:

- They are realistic and promote pupils' intrinsic motivation. With them pupils test their knowledge and experience in real-life situations, thereby giving them the opportunity to link what they have learned in the classroom with extracurricular reality.

- They require reflection and stimulate innovation, as they are not based on pre-set answers. 
- They require from students to seek for alternatives and construct their own knowledge by collecting and organizing data, researching, analysing, generalizing and observing.

- They require students to think critically about their work, learn about themselves, discover their strengths and weaknesses, evaluate their products and to correct and improve results by themselves.

Sentočnik [32] states that authentic tests verify whether students are able to do what they need in real life and what is important to know. Ormiston [25] adds that students do such tasks and solve such problems that enable them to acquire knowledge that is useful in real life outside school.

Luongo-Orlando [16] states that the authentic methods of teaching, learning and assessment of knowledge are based on practical assignments and presentations. Creative work, such as the production of written tasks, projects, experiments, presentations, exhibitions and a map of achievements, allows students a rich learning environment. Therefore, in determining the quality of work new assessments methods which are based on doing tasks that require the use of knowledge and skills in real life situations are introduced in schools.

Fook and Sidhu [4] argue that authentic tasks allow students more opportunities to develop intellectual abilities and via cooperative learning or problem solving tasks promote the development of social skills. Chen, Whittinghill \& Kadlowec [12] add that authentic tasks provide students with more opportunities to practice knowledge and improve the quality of thinking and understanding of the lessons learned. Additionally, Marsh [15] add that authentic assessment takes more practical and realistic tasks, which requires the analysis and integration of knowledge. Furthermore, Wiggins [9] states that if we want to design an authentic test, we must first to decide what the actual performances that we want students to be good at are.

Razdevšek Pučko [3] reports on the positive results of pupils' maps (portfolio) management which are reflected in the way that: teachers make criteria for assessment more carefully; students are more aware of their mistakes; writing reflections on products increases the level of metacognition; students like managing the folders because in such a way of work they learn more since they know the objectives and they see learning in a more practical context. Easley \& Mitchell [29] add that students, based on the knowledge assessment criteria formed together with their teacher, choose their best projects, compare them with the selected projects in the previous assessment period, identify improvements, describe the strengths and weaknesses of the projects, and set goals they will try to achieve in the next project.

\subsection{Evaluation and Assessment in the School Subject Social Studies}

The school subject Social Studies is in the Republic of
Slovenia taught in Years 4 and 5 of primary school in the amount of 2 lessons/week.

For this subject it is also true that assessment is carried out only after we evaluate the students' achievements. For Social Studies there are no standardized tests yet, so a teacher evaluates and assesses knowledge by tests composed by themselves or in school expert groups [22].

Teachers have to strive to maximize the inclusion of authentic forms of assessment which take into account the aspects of procedural, lifelong and useful knowledge. Here it is not only important what students know, but also how they understand and use knowledge. This allows students to show their knowledge and skills in a variety of ways. Authentic forms that are appropriate for the evaluation in the subject Social Studies are simulation; conversation with elderly locals about the town's history and life; connecting with the community and discussion on the possibilities of development of the place; interview with a specialist who deals with furnishing; preparation and conduct of the conference on the topic of violence in the neighborhood; video recording; appearances before different audiences; teaching younger students, and further evaluation of various activities such as research and investigation; data collection; planning; observation; taking notes; editing; representation; interpretation; evaluation etc. One of authentic forms of evaluation are also pupils' maps (a map of achievements, a map of products - portfolio) [21], which are collections of the best examples of somebody's work. Students' feedback from the portfolio development process indicates that the procedure itself made them more aware of their own learning processes, and how they needed to take control of their learning activities to make them more meaningful for personal and professional growth [1].

Rutar Ilc [34] adds to the above listed authentic form also: projection; an expression by non-fiction and artistic texts; discussions, debates and round tables; manufacture of products, scale models and replicas.

In the new curriculum for the subject which became valid in the school year 2011/2012 there is more room for selectivity and openness at the level of content; the curriculum also introduces operational as well as procedural and developmental objectives; there is integration of knowledge within the subject and in interdisciplinary sense; the objectives are not fragmented and they show competencies; updates are on the level of expected results; essential skills are distributed across reasonable periods of time; the curriculum takes into account different types and levels of knowledge [23].

In the above-mentioned curriculum we can also find a recommendation that teachers should plan authentic evaluation and assessment where students apply knowledge to solve real issues and the most realistic problem situations, taking into account the level of development and individual characteristics of pupils. In the assessment, the teacher should create learning situations where students show their skills at realistic and, above all, meaningful tasks [23]. 
Stern survey [18] on the frequency of use of authentic forms of assessment in Social Science classroom in Year 5 showed that among authentic forms of assessment products assessment $(43.2 \%)$ and assessment of solving practical problems $(37.9 \%)$ prevail. They are followed by authentic tests $(28.4 \%)$, cooperative learning $(21.1 \%)$, pupil's self-assessment $(15.8 \%)$, and finally the use of portfolio $(12.6 \%)$. The survey also found that the authentic forms of assessment are not widespread. It was also revealed that a quarter of the interviewed teachers stated that they sometimes assessed homework, the purpose of which is not knowledge assessment. The aforementioned survey also revealed some differences based on the professional title of teachers in solving practical problems and self-assessment. The data show that the use of these declines with lower teachers' professional title. The length of service has also shown some statistically significant differences, namely that teachers who teach for more than 21 years more often make use of authentic forms than teachers with less seniority. The author, based on the results, concludes that the reasons for poor distribution of authentic forms of assessment can be sought in the fact that teachers do not know enough about them, and that they also require from them changing the traditional teaching procedures, so they prefer to make use of standard, more tried and tested methods.

\subsection{Purpose}

Because of the novelty brought by new insights in the field of learning theory and conception of knowledge, more modern forms and methods of teaching and learning are becoming increasingly important. However, such way of work requires from teachers different evaluation and assessment, which have to be coordinated with the course of classes. Therefore, we were interested in how teachers evaluate and assess in the subject Social Science in Year 4.

In the empirical part of the research we studied:

- Teachers' objectives in evaluation and assessment.

- The frequency of authentic and alternative forms of evaluation.

- Implementation of continuous evaluation.

We were interested in the existence of differences depending on seniority, teachers' professional title and the popularity of the subject Social Science.

\section{Method}

We used descriptive and causal non-experimental method of empirical pedagogical research.

For data collection we used an online questionnaire. The study was conducted on a dedicated representative sample of teachers $(\mathrm{n}=288)$ who taught the subject Social Science in Year 4 in Slovenian primary schools. The sample varies according to the seniority of teaching: from 0 to 10 years $(30.9 \%)$, from 11 to 25 years $(38.2 \%)$ over 26 years
(30.9\%); teachers' professional title: the teacher without title $(18.8 \%)$, mentor (36.5\%), consultant (39.9\%), counselor (4.9\%); popularity of teaching the subject Social Science: loves to teach $(34.0 \%)$, likes to teach $(58.3 \%)$, doesn't like to teach that much $(7.6 \%)$. The survey was conducted in March and April 2010.

Data were analyzed with SPSS on the level of descriptive and inferential statistics. We used frequency distribution of data (f, f\%) and nonparametric test $\left(\chi^{2}-\right.$ test).

\section{Results and Interpretation}

Here we present the results of the analysis of empirical research. First, we present the results of the analysis of the objectives of teachers in knowledge evaluation and assessment. Further, we present the analysis of the frequency of use of authentic and alternative forms of knowledge evaluation, then follows the analysis of the implementation of continuous evaluation.

\subsection{Analysis of Teachers' Objectives in the Evaluation and Assessment in the Subject Social Science in Year 4}

We wanted to know what teachers think about the objectives of evaluation and assessment in the subject Social Science in Year 4.

The respondents rated with 1 the objective which they considered the least important, and with 5 the one they deemed the most important.

Table 1. Average values $(\bar{x})$ of the importance of objectives of evaluation and assessment

\begin{tabular}{|c|c|}
\hline LEARNING OBJECTIVES & $\begin{array}{c}\text { AVERAGE } \\
\text { VALUE }\end{array}$ \\
\hline $\begin{array}{c}\text { A teacher obtains feedback for continuous } \\
\text { monitoring of pupils' progress. }\end{array}$ & 4,35 \\
\hline $\begin{array}{c}\text { Learners are provided with feedback on } \\
\text { development and progress. }\end{array}$ & 4,30 \\
\hline $\begin{array}{c}\text { A teacher obtains feedback in order to facilitate the } \\
\text { planning and management of teaching. }\end{array}$ & 4,15 \\
\hline $\begin{array}{c}\text { To motivate students and encourage them to do } \\
\text { more school work. }\end{array}$ & 4,10 \\
\hline A teacher acquires a mark. & 3,04 \\
\hline Students are allocated in learning groups. & 2,67 \\
\hline
\end{tabular}

\subsection{The Results}

The results show that hat teachers, considering knowledge evaluation and assessment, believe that two most important goals are that they know how to obtain information which enables them to monitor the ongoing development and progress of pupils $(\bar{x}=4.35)$, and the objective that the students are able to timely provide high quality feedback about their development and progress 
$(\bar{x}=4.30)$. These two objectives are mutually closely linked, because if a teacher does not constantly monitor and in different ways record how students' progress, it is more difficult for him/her to inform students about their individual progress in all areas of work.

Slightly less important objectives in terms of evaluation and assessment are: teacher's obtaining feedback to facilitate the planning and management of teaching $(\bar{x}=4.15)$, which is left to each teacher individually, and the objective of motivating and encouraging pupils to do more school work $(\bar{x}=4.10)$. The teacher is significantly responsible for how students will be prepared to participate actively at school work, so every teacher should be sensitive enough to notice efforts, and encourages learners to do work.

Teachers did not assign significantly great importance to the objective of teacher's acquiring a mark $(\bar{x}=3.04)$, since that is required from them under current legislation, and the objective of knowledge evaluation and assessment serving as a basis for teachers to allocate pupils into learning groups $(\bar{x}=2.67)$. Every teacher sets their own criteria to help determine the groups of students who most actively work within the group and where each student has their specific and defined role.

Popularity of teaching is a factor where there are differences and difference tendencies. We found that teachers who like teaching the subject Social Science assign a higher importance to the objective "a teacher acquires a mark" ( $\left.\mathrm{P}=0.003 ; \chi^{2}=23.654\right)$ than the other two groups of teachers. The tendencies show that teachers who more like teaching, assign higher importance to the objectives of "a teacher obtains feedback in order to facilitate the planning and management of teaching" ( $\left.\mathrm{P}=0.099 ; \chi^{2}=7.794\right)$, "to motivate students and encourage them to do more school work" $\left(\mathrm{P}=0.062 ; \chi^{2}=8.981\right)$, and "students are allocated in learning groups" ( $\left.\mathrm{P}=0.088 ; \chi^{2}=11.002\right)$. To sum up, teachers who like teaching the subject Social Science, consequently, due to higher intrinsic motivation, ascribe more importance to the individual objectives of evaluation and assessment.

\subsection{Analysis of the Frequency of Use of Authentic and Alternative Forms of Evaluation}

We wanted to know how often teachers make use of certain authentic and alternative forms of evaluation in the subject Social Science in the Year 4. The subjects of research were authentic forms of knowledge evaluation: portfolio, interview, video recording, research, experiment and two alternative forms of knowledge evaluation: simulation and projection.

The respondents filled out a 3-step scale of frequency of use of certain types of knowledge evaluation forms (1 meant often, 3 meant never).
Table 2. Average values $(\bar{x})$ of frequency of different forms of evaluation.

\begin{tabular}{|c|c|}
\hline EVALUATION FORMS & $\begin{array}{c}\text { AVERAGE } \\
\text { VALUE }\end{array}$ \\
\hline Research & 2,23 \\
\hline Simulation & 2,23 \\
\hline Projection & 2,33 \\
\hline Experiment & 2,45 \\
\hline Interview & 3,04 \\
\hline Portfolio & 3,11 \\
\hline Video & 3,30 \\
\hline
\end{tabular}

Calculation of average values shows that among all alternative and authentic forms of knowledge evaluation teachers most often choose an evaluation in the forms of researching specific topics $(\bar{x}=2.23)$ and simulation $(\bar{x}=2.23)$. In slightly fewer cases teachers select projection $(\bar{x}=2.33)$ and the experimental work $(\bar{x}=2.45)$, followed by an interview $(\bar{x}=3.04)$ and portfolio $(\bar{x}=3.11)$. The least often teachers evaluate by using videos $(\bar{x}=3.30)$ recorded by pupils.

From the above results we conclude that teachers are aware of the importance of active forms of evaluation, since when accompanied by good organization students' activity in research is very intense, and consequently the knowledge gained that way is more durable. Teachers often choose a simulation where "pupils play themselves in an imaginary situation as if it were real" [5]. This motivates pupils and prepares them for practical life situations. To use this method in a classroom we have to have a clear objective which students should be familiar with, and at the end discussion and reflection are necessary [22]. Students also get emotionally involved in situations and this way learn to accept diversity in humans. Due to diverse benefits of using portfolio, including a high rate of authenticity as products are typically an integral part of the learning process, and that portfolio is an ideal tool for monitoring pupils' progress which we encourage students' self-assessment with [6], a low use of it is surprising. The finding is comparable with the Slovenian research conducted by Antolin [11] which found that a low percentage of portfolio use as a form of evaluation is due to rather low awareness of this form. The reason for such a rare use of video could be teachers' fear of the agreed clip being filmed by an adult which is not an objective of knowledge evaluation, or their being anxious about the technical approach, because many children do not have the necessary equipment to record or parents do not allow the handling of it.

From the results of tests of differences, it can be summarized that the popularity of teaching is a factor where differences appear. Namely, we found statistically 
significant differences in the frequency of knowledge evaluation by interview ( $\left.\mathrm{P}=0.002 ; \chi^{2}=16.595\right)$, exploration $\left(\mathrm{P}=0.012 ; \chi^{2}=12.807\right)$, video $\left(\mathrm{P}=0.042 ; \chi^{2}=9.924\right)$ and performing experiments $\left(\mathrm{P}=0.027 ; \chi^{2}=7.196\right)$. These forms of evaluation are, as expected, most frequently used by teachers who love to teach the subject Social Science. We believe that these teachers spend a lot of time for updating their knowledge and introducing innovations in the learning process, which is also reflected in the quality and variety of their teaching.

\subsection{Analysis of the Implementation of Continuous Evaluation}

We were interested in how teachers implement continuous evaluation of pupils.

The respondents filled out a 3-step scale of frequency of use of certain types of evaluation ( 1 meant often, 3 meant never).

Table 3. Average values ( $\mathrm{x} \square$ ) of different types of evaluation

\begin{tabular}{|c|c|}
\hline TYPES OF EVALUATION & $\begin{array}{c}\text { AVERAGE } \\
\text { VALUE }\end{array}$ \\
\hline SUMMATIVE & 1,03 \\
\hline DIAGNOSTIC & 1,38 \\
\hline FORMATIVE & 1,46 \\
\hline
\end{tabular}

The results show that in practice summative evaluation, carried out after the discussion of learning content, prevails. Teachers can in this way successfully verify the quality of their teaching and how well pupils memorized the new learning content. Then follows a diagnostic evaluation which "is performed at the beginning of teaching to determine prior knowledge: its scope and structure" [2], and after that formative evaluation that "takes place throughout the process of teaching and learning" [22]. Continuous examination was not statistically subject to any independent variable.

\section{Conclusions and Suggestions}

Evaluation and assessment of students is always a delicate and topical area of educational work which requires teachers' detailed knowledge of its legality, accountability, propriety, system, consistency and fairness.

As evaluation and assessment in the learning process are very important and responsible steps for teachers, they dictate researchers to discover, in context of empirical research, conditions and guidelines to improve this area. With this in mind we approached our own research.

On a representative sample of teachers who participated in our study we found that:

- The teachers assigned the greatest importance to these two interconnected goals: "a teacher obtains feedback for continuous monitoring of pupils' progress" and "earners are provided with feedback on development and progress".

- In evaluation teachers among authentic forms most commonly choose research, which is followed by evaluation by means of experiment, interview, portfolio and video. Among the alternative forms teachers slightly more often choose simulation and projection.

- The majority of teachers use summative evaluation, a little less diagnostic and even less formative evaluation.

On this basis we derive the following guidelines:

1. In general, formative assessment takes place while learning is still taking place so that instructors can adjust their instruction to best meet the current learning needs of their students. They are informal, discrete and frequent, as often as every few minutes. Examples of formative assessment include discussion, interpretation of nonverbal cues, pre-tests, summary writing, think-pair-share, and using clickers or hand signals for class polls [24]. Consequently more attention should be paid to monitoring the formative processes of learning and achievements of each pupil, as presented in the articles of the new Rules on knowledge assessment and grading and students' progress to a higher class standing in elementary schools from 2013 [28].

Furthermore, the Tridane, Belaaouad, Benmokhtar, Gourja, Radid survey [26] on the impact of formative assessment on the learning process showed that formative assessment can help teachers to anticipate the treatment of the students' knowledge gaps in advance, and change methods, if necessary, in the course of learning process. On the other hand, summative assessment may not reflect the level of acquisition of the taught concepts. Therefore the revision of assessment methods of the concepts among learners is required.

In addition, since the boundaries between formative and summative assessment of knowledge is somewhat blurred, it is necessary to encourage the students to be always critically involved in the teacher's feedback. Harlen (cited in [33]), believes that feedback is most effective in promoting learning where students are involved in the process of deciding on the next steps and not just passive recipients of the teacher's assessment of their work.

2. Changing the practice of testing and assessment is a lengthy process which requires from teachers enormous effort, courage to try something new and to actively change their own behavior and beliefs. In Addition, Borstner [20] believes that teachers will be able to effectively introduce changes to their teaching if they are properly motivated, if there is clearly defined theoretical basis, and if there are, in the process of developmental work, appropriate educational materials created that will support the 
introduction of innovations in teaching.The Zabukovec survey [27] showed that teachers are acquainted with more modern forms, but they use traditional forms more often as they are easier to execute and less time consuming. For this reason within the framework of school expert groups or training it is needed to give teachers the opportunity to practice using authentic and alternative forms.

3. The planning of continuous evaluation is required and the students have to be provided with timely feedback on their development and progress in all areas of work.

In conclusion, the undergraduate teacher education should, in terms of knowledge evaluation and assessment, represent a solid basis for further professional growth process. Teachers' education should not end with receiving a degree, but, as stated by Kalin [14], the initial training should be followed by the possibility of implementing the relevant continuous education which is focused on different needs of teachers' professional growth, including reflective elements. The curriculum reform in Slovenia with its own guidelines requires a modified view on a teacher's role [10]. This is mainly reflected in the creation of opportunities for students to build the knowledge and skills to successfully live and work in modern society. If a teacher wants to implement this new role, they have to acquire new knowledge and skills, and begin to change their beliefs and implicit theories that are associated with knowledge and influence the way they teach, evaluate and assess [31]. Furthermore, Darling-Hammond \& Snyder [19] add that the demands of teaching more challenging content to more diverse learners suggest a need for teacher education that enables teachers to become more sophisticated in their understanding of the effects of context and learner variability on teaching and learning. Instead of implementing set routines, teachers need to become ever more skilful in their ability to evaluate teaching situations and develop teaching responses that can be effective under different circumstances.

New extensive literature, such as updated curricula, provided guidelines for teachers based on curricular reforms, and researches on evaluation and assessment give evidence that school records, related to the assessment of knowledge, comply with new approaches and guidelines in this area. However, in practice a lot remains to be done.

With our research we found that teachers in Slovenian primary schools are familiar with guidelines of contemporary knowledge evaluation and assessment, but the frequency of these forms in practice is differently represented. The popularity of teaching the subject Social Studies is a factor, in connection with which statistically significant differences or trends show most frequently. From this we can conclude that regardless of this factor requires all teachers should be encouraged and motivated to introduce new features and improvements to their work, because this is how students, who should be constantly involved in the process of evaluation and assessment of knowledge, will benefit most. Pupils should be able to demonstrate their knowledge in different ways and in authentic problem situations. Teachers should be offered opportunities for further education, support by professionals and high-quality professional literature, from which to draw ideas for their work.

\section{REFERENCES}

[1] B. L. Wilcox \& L. A. Tomei. Professional portfolios for teachers: A guide for learners, experts, and scholars, Norwood, MA: Christopher-Gordon, 1999. Online available from https://eric.ed.gov/?id=ED470241

[2] B. Marentič-Požarnik \& C. Peklaj. Preverjanje in ocenjevanje za uspešnejši študij, Ljubljana, Center za pedagoško izobraževanje Filozofske fakultete, 2002.

[3] C. Razdevšek-Pučko. Drugačne oblike preverjanja in ocenjevanja znanja, Sodobna pedagogika, Vol. 47, No. 9-10, 114-119, 1996.

[4] C. Y. Fook \& G. K. Sidhu. Authentic Assessment and Pedagogical Strategies in Higher Education, Journal of social sciences, Vol. 6, No. 2, 153-161, 2010. Online available from http://thescipub.com/html/10.3844/jssp.2010.153.161

[5] D. Majcen. Didaktične igre pri pouku spoznavanje okolja zunaj učilnice, Magistrsko delo, 2014. Online available from https://dk.um.si/Dokument.php?id=66583

[6] D. Skribe-Dimec. Preverjanje in ocenjevanje, Vol. 2, No. 1, 45, 2005.

[7] D. Skribe-Dimec. S preverjanjem znanja do naravoslovne pismenosti, Ljubljana, DZS, 2007.

[8] F. Strmčnik. Didakta, Ljubljana, Znanstveni inštitut Filozofske fakultete, 2001

[9] G. Wiggins. A True Test: Toward More Authentic and Equitable Assessment, Phi Delta Kappan, Vol. 70, No. 9, 700-713, 1989. Online available from https://grantwiggins.fil es.wordpress.com/2014/01/wiggins-atruetest-kappan89.pdf

[10] Izhodišča kurikularne prenove. Ljubljana, Nacionalni kurikularni svet, 1996.

[11] J. Antolin. Portfolio kot oblika preverjanja in ocenjevanja znanja, Diplomsko delo, Maribor, Univerza v Mariboru, 2010. Online available from https://dk.um.si/IzpisGradiva.php?id=1 4511

[12] J. C. Chen, D. C. Whittinghill \& J. A. Kadlowec. Rapid Assessment for the Improved Student Learning and Satisfaction, Proceeding on the National STEM Assessment Conference, 2006. Online available from https://www.researchgate.net/profile/Michael_Klymkowsky/ publication/238533299 Ed's Tools A Web-based Software Toolset_for_Accelerated_Concept_Inventory_Construction/ $\overline{\text { links }} / 004635320 \mathrm{a} 2 \mathrm{~d} 9 \mathrm{f} 26 \mathrm{dc} 000000 . \overline{p d f} \#$ page $=\overline{50}$

[13] J. E. Raymond, C. S. E. Homer, R Smith \& J. E. Gray. Learning through authentic assessment: An evaluation of a new development in the undergraduate midwifery curriculum, 
Nurse Education in Practice, Vol. 13, No. 5, 471-476, 2013. Online available from http://www.sciencedirect.com/science/ article/pii/S1471595312001941

[14] J. Kalin. »Izkušnja - refleksija - delovanje« v procesu profesionalnega razvoja učiteljev. In: Marentič-Požarnik, B. (ur.), Konstruktivizem v šoli in izobraževanje učiteljev, Ljubljana, Center za pedagoško izobraževanje Filozofke fakultete, 597-613, 2004.

[15] J. Marsh. Šolsko ocenjevanje na holističen način. In: Komljanc, N. (ur.), Didaktika ocenjevanja znanja: vodenje procesa ocenjevanja za spodbujanje razvoja učenja: zbornik prispevkov. Ljubljana, Zavod RS za šolstvo, 2009.

[16] K. Luongo-Orlando. Drugačno preverjanje znanja. Predlogi za avtentično spremljanje napredka učencev, Ljubljana, Založba Rokus Klett, d.o.o., 2008.

[17] Konstruktivizem v šoli in izobraževanje učiteljev. Ljubljana, Center za pedagoško izobraževanje Filozofske fakultete, 2004.

[18] K. Štern. Preverjanje in ocenjevanje pri pouku družbe v petem razredu, Diplomsko delo, Maribor: Pedagoška fakulteta, 2010. Online available from https://dk.um.si/IzpisGradiva.php?id=1 6706

[19] L. Darling-Hammond \& J. Snyder. Authentic assessment of teaching in context, Teaching and Teacher Education, Vol. 16, No. 5-6, 523-543, 2000. Online available from http://www.sciencedirect.com/science/article/pii/S0742051X 00000159

[20] M. Borstner. Posodobljeni učni načrti za gimnazijo ter procesi preverjanja in ocenjevanja znanja. In: M. Borstner, A. Žakelj (ur.), Razvijanje in vrednotenje znanja, Ljubljana, Zavod RS za šolstvo, 2012.

[21] M. Budnar, M. Umek \& M. Zabukovec. Opisno in številčno preverjanje in ocenjevanje pri predmetu družba, Vzgoja in izobraževanje, Vol. 33, No. 6, 19-33, 2002.

[22] M. Budnar, V. Hus, M. Umek \& M. Zabukovec. DRUŽBA 4. razred: načrtovanje, poučevanje, učenje, ocenjevanje, Ljubljana, Zavod Republike Slovenije za šolstvo, 2006.

[23] M. Budnar, M. Kerin, M. Umek, M. Raztresen \& G. Mirt. Učni načrt: program osnova šola. Družba, Ljubljana, Ministrstvo za šolstvo in šport, Zavod Republike Slovenije za šolstvo, 2011.

[24] M. J. Snyder Broussard. Perspectives On Using Games to Make Formative Assessment Fun in the Academic Library, The Journal of Academic Librarianship, Vol. 40, 35-42, 2014.
Online available from http://www.sciencedirect.com/science/ article/pii/S0099133312002054

[25] M. Ormiston. Creating a Digital-Rich Classroom: Teaching \& Learning in a Web 2.0 World, Solution Tree Press, Vol 2-3, 2011. Online available from https://www.amazon.com/Creati ng-Digital-Rich-Classroom-Teaching-Learning/dp/19352498 78

[26] M. Tridane, S. Belaaouad, S. Benmokhtar, B. Gourja \& M. Radid. The impact of formative assessment on the learning process and the unreliability of the mark for the summative evaluation, IOSR Journal of Research \& Method in Education (IOSR-JRME), Vol. 5, No. 2, 48-51, 2015. Online available from

http://www.iosrjournals.org/iosr-jrme/papers/Vol-5\%20Issue2/Version-2/G05224851.pdf

[27] M. Zabukovec. Medsebojni vplivi metod poučevanja in oblike preverjanja znanja pri predmetu spoznavanje družbe, Pedagoška obzorja, Vol. 16, No. 3, 16-30, 2001.

[28] Pravilnik o preverjanju in ocenjevanju znanja ter napredovanju učencev v osnovni šoli (Uradni list RS, št. 52/2013). Online available from http://www.uradni-list.si/1/objava.jsp?sop=20 13-01-1988

[29] S. D. Easley \& K. Mitchell. Portfolio v ocenjevanju: kaj, kje, kdaj, zakaj in kako ga uporabiti, Nova Gorica, Educa, Melior, 2007.

[30] Skupina za reforme ocenjevanja. Ocenjevanje za učenje, Ljubljana, Zavod Republike Slovenije za šolstvo, 2009.

[31] S. Sentočnik. Avtentične oblike preverjanja in ocenjevanja za kakovostnejše učenje in poučevanje, Vzgoja in izobraževanje, Vol. 31, No. 2-3, 82-86, 2000.

[32] S. Sentočnik. Kritična refleksija: predpogoj za učiteljevo avtonomijo in spodbuda kakovostnemu učenju. In: Marentič-Požarnik, B. (ur.), Ljubljana, Center za pedagoško izobraževanje Filozofske fakultete, 583-596, 2004.

[33] S. Stralberg Bagley. Students, teachers and alternative assessment in secondary school: Relational Models Theory (RTM) in the Field of Education, The Australian Educational Researcher, Vol. 37, No. 1, 83-106, 2010. Online available from https://link.springer.com/article/10.1007/BF03216915

[34] Z. Rutar Ilc. Pristopi k poučevanju, preverjanju in ocenjevanju, Ljubljana, Zavod Republike Slovenije za šolstvo, 2003. 